\title{
一様な鉛直下降流中に置かれた水平上向き加熱平板まわりの 強制-自然共存対流の流動と伝熱*
}

\author{
北村 健 三*1, 光 石 暁 彦*1，木 村 文 義*2
}

\section{Fluid Flow and Heat Transfer of Combined Convection over Upward-Facing, Horizontal, Heated Plates Placed in Vertical Downward Flow}

\author{
Kenzo KITAMURA*3, Akihiko MITSUISHI and Fumiyoshi KIMURA
}

${ }^{* 3}$ Department of Mechanical Engineering, Toyohashi University of Technology,

1-1 Hibarigaoka, Tempaku-cho, Toyohashi-shi, Aichi, 441-8580 Japan

\begin{abstract}
Experimental investigations have been carried out on combined convective flows induced around the upward-facing, horizontal heated plates placed in a vertical downward flow of forced convection. The experiments were performed both with water and air and in the ranges of the Reynolds and modified Rayleigh numbers as ; $300<R e_{W}<5000,10^{7}<R a_{W}^{*}<10^{10}$ for water, and $200<R e_{W}<2000,10^{6}$ $<R a_{W}^{*}<10^{9}$ for air. The flow fields over plates are visualized with dye and smoke. The results showed that the longitudinal vortices of which axes are parallel to the flow direction appear over the plate when the buoyancy force is beyond critical, and that the onsets of the longitudinal vortices are expressed with the non-dimensional parameter as; $G r_{W}^{*} / \operatorname{Re}_{W}^{2.5}=4.0$ for water and $G r_{W}^{*} / \operatorname{Re}_{W}^{2.5}=1.77$ for air. The local heat transfer coefficients of the plate were also measured. The results showed that the coefficients are increased significantly from those of the laminar wedge flows of forced convection with increasing the buoyancy force. The mechanisms and the critical conditions for the enhancement of heat transfer were also discussed.
\end{abstract}

Key Words: Combined Convection, Thermal Instability, Heat Transfer, Wedge Flow, Longitudinal Vortex

\section{1. 緒言}

図 1 に示すように，鉛直下方に一様な流速で流れる 流体中に，有限な大きさの加熱平板が水平上向きに設 置され, 平板から流れに向かって熱が移動する体系は, 様々な伝熱機器・装置あるいは我々の身近で遭遇する 体系の一つである.この体系下では，平板の上面側に よどみ点流れ(Stagnation point flow) あるいは Hiemenz flow ${ }^{(1)}$ と呼ばれる流れが生じる.このよどみ点流れ場 では，岐点を中心とする広い範囲に亘って一样な熱(物 質）伝達率が実現される(2)ことから，最近では，シリ コンやガラス等の基板上に薄膜を形成するに当たって, このよどみ点流れがよく利用されている．例えば，横 置型常圧コールドウォール熱 CVD 炉では，水平に設 置した基板を下方からヒータで加熱し，基板上方から 原料ガスを鉛直下向きに流すことにより，基板上に層 流よどみ点流れを実現し，均質な薄膜を形成する方法 が採用されている，このよどみ点流れを実現するには 十分速い速度で原料ガスを流せば良いが，原料ガスは 高価であり，原料ガスの収率を上げるためには，なる

* 原稿受付 2009 年 4 月 20 日.

*1 正員, 豊橋技術科学大学工学部機械システム工学系 (王 4418580 豊橋古天伯町零雀方丘 1-1).

*2 正員, 兵庫県立大学大学院工学研究科機械系工学專攻 (牙 671-2280 姫路市書写 2167).

E-mail : kitamura@mech.tut.ac.jp
ぶくガスの流量（流速）を低く抑えたいとの要求があ る. 一方, ガスの流速が遅くなると, 加熱された基板 まわりに生じる浮力が流れに影響を及ぼし，基板上の 流孔は，安定した層流上どみ点流れから不安定もしく は局所的に不均一な流れ几と変化するものと予想され る. では，浮力が作用した場合に，一体どのような流 れや流動不安定が基板上に生じるかという問題である が，著者らが調べた限り，今まで層流よどみ点境界層 流れの安定性を論じた解析(3)(4) がわずかに試みられ ている程度で，実際に加熱平板上にどのような流動不 安定が生じるかについては，現在でもほとんど不明の ままである.

このことから，本研究では上向き加熱平板上の強制 一自然共存対流の基本的な流動・伝熱特性を，実験を 通じて解明することにした，具体的には，図 1 に示す
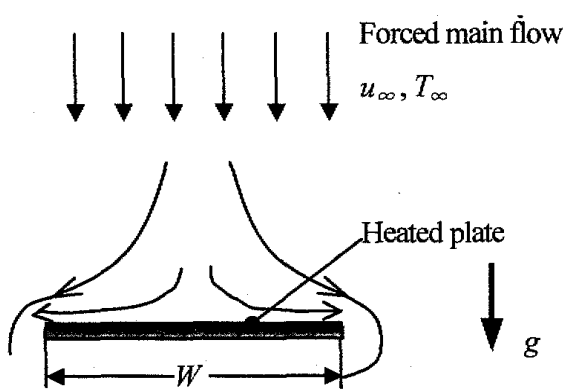

Fig. 1. Present flow configuration 
体系, すなわち一様な流速 $u_{\infty}$ およひ温度 $T_{\infty}$ の鉛直下 降流中に，有限な大きさの加熱平板が水平上向きに設 置された体系を対象に，まず流れの可視化を行い，浮 力の作用により，上向き平板上にどのような流動不安 定あるいは流れの変化が生じるかを調べることにした。 また，この流動不安定が加熱平板の局所の伝熱特性に 如何なる影響を及ぼすか地，感温液晶を用いた平板表 面温度の可視化およひ熱電対を用いた局所熱伝達率の 測定を通じて探ることにした．体系をなるべく単純化 するため，試験平板には 2 次元矩形平板を用い，平板 を等熱流束条件で加熱した．また試験流体として，実 験が容易な常温の水および空気を用いることにした。 本研究で得られる一連の成果は，上述した熱 CVDに よる製膜問題だけでなく，様々な発熱物体まわりの流 動・伝熱問題あるいは局地気象学の問題などにも有益 な資料を提供するものと考えている。

\section{2. 実験装置および測定}

本研究で用いた実験装置の構成および主要な寸法諸 元を図 2 に示寸．図 2(a)は水実験用の縦型回流水槽, 図 2(b) 惊気実験用の縦型吸込式小型風洞を示してい る.まず, 図2(a) の回流水槽であるが, リザーバに溜 められた水は，ポンプにより上部整流胴内に送り込ま れ，整流胴内に設置されたメッシュ，アルミハニカム およひ縮流ノズルを経て，一様かつ低乱れ度の流れに 整流された後, 断面 $250 \times 250 \mathrm{~mm}^{2}$ の試験ダクト内に流 入する. その後, ダクトを出た水はリザーバへと戻る. 一方，図 2(b) の縦型風洞であるが，実験室内の空気を 整流胴上部から吸い込み，メッシュ，アルミハニカム および縮流ノズルにより一様かつ低乱れ度の流れに整 流する. その後，空気は断面 $300 \times 300 \mathrm{~mm}^{2}$ の試験ダク ト内に流入し, ブロワーにより実験室内へ排出される.

試験平板は上述した水および空気用試験ダクト内に， 縮流ノズル出口より $150 \mathrm{~mm}$ 下方の地点に水平上向き に設置した．回流水槽内を流れる水の流量はダクト下 流側に設けた流量調整弁で，また風洞内を流れる空気 の流量はブロワーの回転数を電㽵調整器で調節するこ とにより，それぞれ所定の值に設定した。なお，試験 平板設置位置におけるダクト内の流速を LDV により 計測した結果によれば，水のダクトでは壁面から $20 \mathrm{~mm}$, 空気のダクトでは壁面から $30 \mathrm{~mm}$ 以内の領域 を除いたダクト中心断面内で, 時間平均流速は $\pm 3 \%$ の 範囲内で一様であり，その乱れ度は最大でも 5 7\% 以 下であった。

つぎに，本実験で用いた試験平板を図 2(c) に示す. 水実験用の試験平板には長さ $L=240 \mathrm{~mm}$, 幅 $W=50$ お よび $75 \mathrm{~mm} の 2$ 種類を，また空気実験用には長さ $L=$
$290 \mathrm{~mm}$, 幅 $W=50,70$ および $100 \mathrm{~mm} の 3$ 種類の試験平 板を製作・使用した．平板のアスペクト比を高くとる ことにより，平板上の流れが 2 次元的になるようにし た.これら試験平板は，アクリル板の片側表面に厚さ $30 \mu \mathrm{m}$ のステンレス箔を貼り付けたもので，箔に交流 を通電することにより等熱流束条件で加熱した. また， これら試験平板の裏面側に厚さ $20 \mathrm{~mm}$ の発泡スチロー ル製断熱板を 2 枚接着し，熱伝導損失を防止した. 試 験平板の流れ力向の局所熱伝達率を測定するため, 平 板のスパン方向中心線上の䇴ヒー夕裏面に線径 100 $\mu \mathrm{m} の \mathrm{~K}$ 型熱電対を，所定の間隔でスポット溶接し，

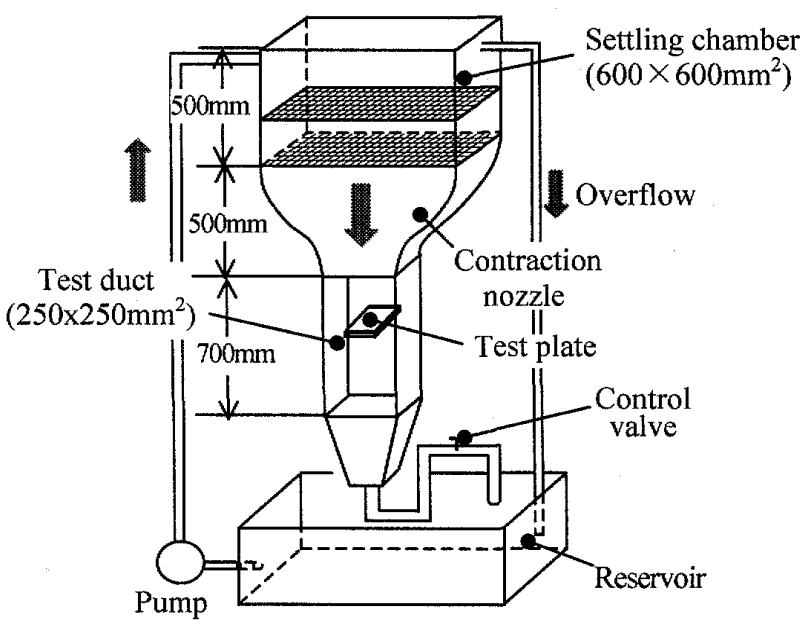

(a) Vertical water tunnel

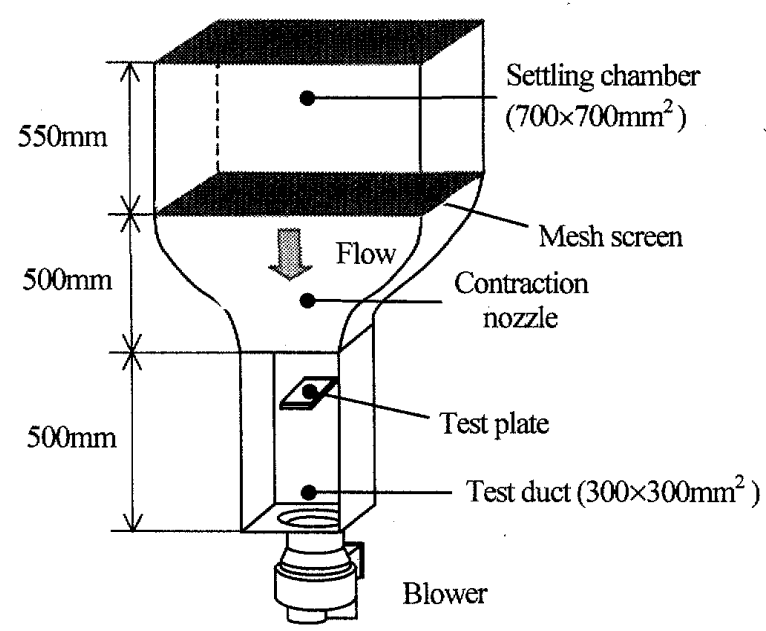

(b) Vertical wind tunnel

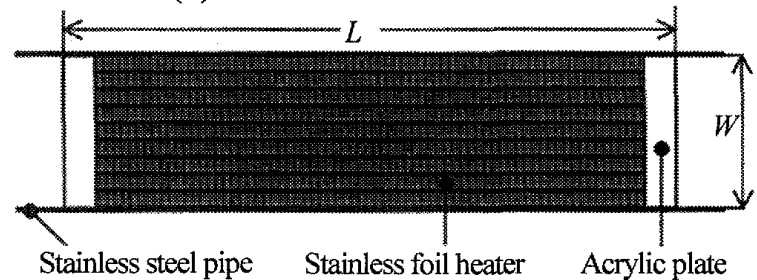

(c) Test plate

Fig.2. Experimental apparatus 
局所壁温 $T_{w x}$ を計測した. なお，空気の伝熱実験では, 対流伝熱量に比してヒータ表面からの放射熱損失およ び裏面への熱伝導損失が無視できないと考えられる。 そこで, 実験ではこの放射熱流束 $q_{r}$ を無限空間への放 射を仮定し，次式により求めることにした。

$$
q_{r}=\varepsilon \sigma\left(T_{w x}^{4}-T_{\infty}^{4}\right)
$$

ここで, $\sigma$ はステファン・ボルツマン定数, $\varepsilon$ は平 板表面の放射率であり，予め検定したステンレス箔の 放射率 $\varepsilon=0.16$ を採用した。 また， $T_{\infty}$ は強制対流主流 温度であり，縮流ノズル出口部に設置した熱電対によ り測定した. 一方, 平板裏面側人の熱伝導損失である が,発泡スチロール断熱材の表裏面に熱電対を接着し, その温度差を基に，一次元熱伀導を仮定し，漏洩熱流 束 $q_{\text {cond }}$ を求めた。 そして, 平板表面の対流熱流束 $q_{w}$ を，ヒー夕加熱量から求めたジュール熱流束 $q_{j}$ から, 上の放射損失熱流束 $q_{\mathrm{rad}}$ およひ熱伝導損失熱流束 $q_{\mathrm{cond}}$ を差し引く, すなわち $q_{w}=q_{j}-\left(q_{r a d}+q_{c o n d}\right)$ で算出した. さらに, この対流熱流束 $q_{w}$ を基に, 局所熱伝達率 $h_{x}$ を次式で定義し, その值を求めた。

$$
h_{x}=q_{w} /\left(T_{w x}-T_{\infty}\right)
$$

なお，本実験範囲内で $q_{\text {rad }}$ および $q_{\text {cond }}$ は，空気の場 合，ジュール発熱熱流束 $q_{j}$ に対してそれぞれ 7-9\%, 10 $-12 \%$ 程度の值となった. また, 水の場合 $q_{\text {cond }} / q_{j}$ の值は 2 -4\%程度となった。

一方，本実験では平板まわりの流れを，水について は蛍光染料で, また空気については線香の煙により可 視化した。これら染料および煙は，試験平板に貼り付 けた箔ヒータ間の腺間に開けたスリットから膜状に流 出させた. 以上の実験装置により害現された強制対流 主流流速 $u_{\infty}$ おじ平板幅 $W$ 基準のレイノルズ数 $R e_{W}$ $\left(=u_{\infty} W / v\right)$ および修正レイリ一数 $R a_{W}{ }^{*} \quad\left(=g \beta q_{w} W^{4}\right.$ $\mid \lambda \alpha v)$ は; 水の場合, $300<R e_{W}<5000,10^{7}<R a_{W}{ }^{*}<10^{10}$, 空気の場合, $200<R e_{W}<2000,10^{6}<R a_{W}{ }^{*}<10^{9}$ であっ た.なお，これら無次元数中の体膨張率 $\beta$ 以外の物性 值については, 膜温度 $T_{f}\left(=\left(T_{w x}+T_{\infty}\right) / 2\right)$ で評価し, また体膨張率 $\beta$ にいては, 水では以下の式(3)により, また空気では， $\beta=1 / T_{\infty}$ で求めた。

$$
\beta=\frac{\rho_{\infty}-\rho_{f}}{\rho_{f}\left(T_{f}-T_{\infty}\right)}
$$

\section{3. 実験結果および考察}

3・1 流れの可視化 まず平板まわりにどのような 流れが生じるか, 染料および煙をトレ一サとした可視 化により調べてみた．その代表的な結果を水および空
気の場合について，図 3 および図 4 にそれぞれ示す. これらの図はいずれも，強制対流主流速 $u_{\infty}$ を一定に 保ち, 熱流束 $q_{w}$ を順次増加させていったときの可視化 結果を示したものである. 平板の長手方向斜め上から 写真を撮影しており，強制対流主流は，図 3(a)の矢印 に示すように上から下に向か⿰て流れ，図中 center と 記した平板中央部で平板に衝突した後，手前側と奥側 に分貱し，平板の両端部(edge)に向かって流れていく. まず，平板を加熱しない図 3(a)の結果であるが，スリ ットから出た染料は，平板表面に沿って膜状に流れ， そのまま平板の両端部人と至っている.この可視化結 果から，平板上には層流よどみ点流れが実現されてい ることが分かる，つぎに平板を加熱し，熱流束を増加 させていくと, 熱流束の低、場合は, 図 3(a) と同様, 平板上に層流よどみ点流れが発達するが，熱流束を $1000 \mathrm{~W} / \mathrm{m}^{2}$ まで増加させると, 図 3(b)に示すように, 染料の一部が筋状に立ち上がるようになる。 そして, さらに熱流束を増加させていくと，図 3(c)あるいは図 3(d) に示すように，平板から立ち上がる筋の数が増え， しかもその高さが高くなる様子が読み取れる.なお, この筋は, 熱流束が小さな場合はほぼ同じ位置に留ま るが，熱流束が大きくなるにつれて平板のスパン方向 に動き始め，筋同士が合体する現象が見られるように なる.また，図には示していないが，さらに熱流束を 増加させていくと，筋はさらに高く立ち上がり，また 形が崩れて不規則となり，平板上の流孔は複雑かつ乱

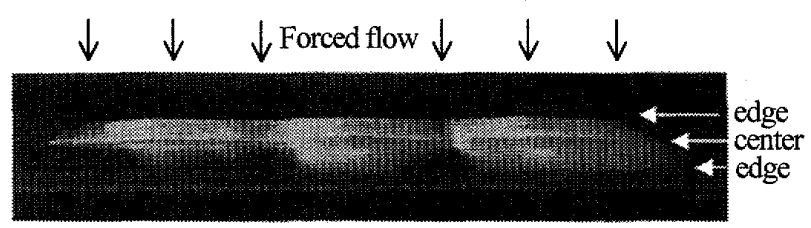

(a) $q_{w}=0 \mathrm{~W} / \mathrm{m}^{2}$

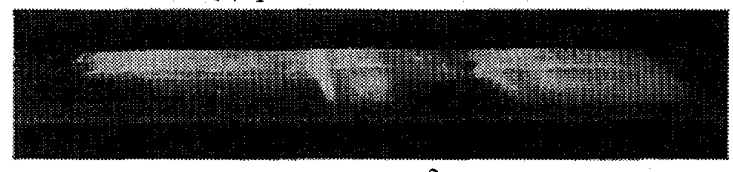

(b) $q_{w}=1000 \mathrm{~W} / \mathrm{m}^{2}$

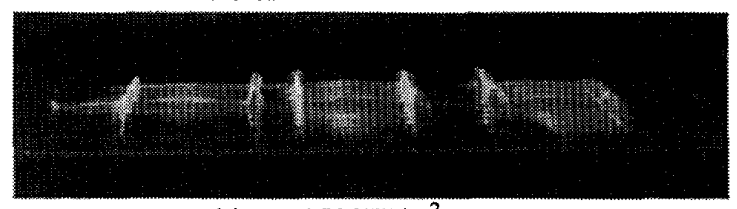

(c) $a_{w}=1500 \mathrm{~W} / \mathrm{m}^{2}$

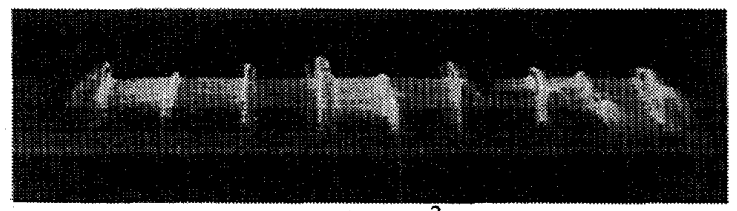

(d) $q_{w}=2000 \mathrm{~W} / \mathrm{m}^{2}$

Fig.3. Visualized flow field over plate (Water, $W=75 \mathrm{~mm} / \mathrm{s}, u_{\infty}=1.0 \mathrm{~cm} / \mathrm{s}$ ) 
れた流れへと移行していくことを確認している. 図 4 に示した空気の可視化結果も，基本的に水之同様であ り,この場合, 熱流束 $q_{w}$ が $50 \mathrm{~W} / \mathrm{m}^{2}$ を越えた辺りから， 図 4(b)に示すような煙の筋が平板上に観察されるよう になる. さらに熱流束を増加させていくと, 図 4(c), (d) に示すように，煙の筋の数および高さが高くなってい く. また, 同時に筋が左右に摇動して, 筋同士の合体 が頻繁に起こるようになる. そして，平板上の流れは 最終的に不規則かつ乱れた流れへと遷移していく.

ところで，本体系下でこのような染料や煙の筋が生 じることは，今まで全く報告されておらず，本可視化 結果は, 上向き加熱平板上のよどみ点流れの不安定現 象を初めて明らかにした点で重要といえる. そこで本 研究では,このような筋が生じるメカニズムについて， 流れの可視化によりさらに詳しく調べてみた. 図 5(a) は，空気の場合について，筋まわりの流れを平板の横 方向からクローズアップ撮影した結果を示している. この図から，煙の筋が立ち上がる部分に一対のマッシ ユルーム型の渦が生じている様子が読み取れる。この 渦は流れ方向に軸をもつ縦渦であり，図4に示寸煙の 筋は，この縦渦の発生に伴って生じることが分かる. つぎに，この煙が立ち上がっている部分を平板の正面 側から写真撮影した結果を図 5(b) に示す.この図を見 ると，煙は平板中心で最も高く立ち上がり，立ち上が った煙は平板端部に向加て左右対称に流れていくこ とが分かる.この煙の外縁は，図 5(a) のマッシュルー 么渦の傘の頂上部分に，また図 5(b)で煙の外縁から少 し下方に連続した薄い煙の筋が見えるが，この筋は金 の下の部分に相当している. このように縦渦の形成に 伴って，平板上に連続した渦管が形成される現象は工 学的に非常に興味樑いといえる.

$3 \cdot 2$ 縌渦の発生開始条件 以上の可視化結果より, 浮力がある程度以上大きくなると, 平板上に流れ方向 に軸をもつ縦渦が発生し，これに伴って平板上の流れ

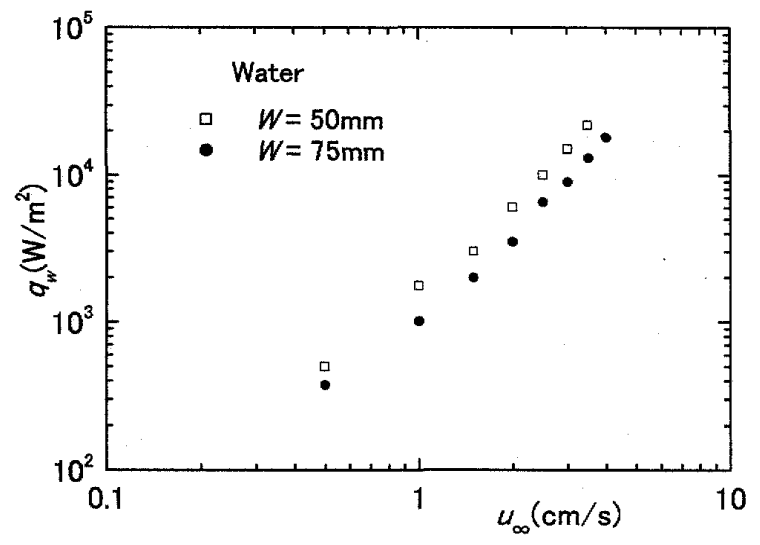

(a) Water

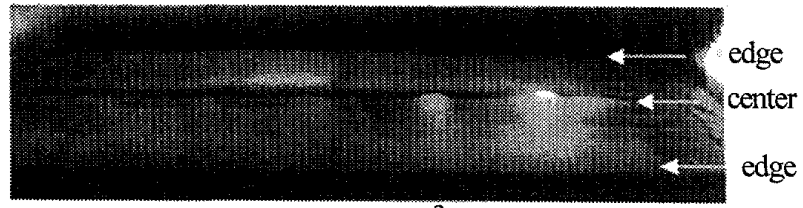

(a) $q_{w}=0 \mathrm{~W} / \mathrm{m}^{2}$

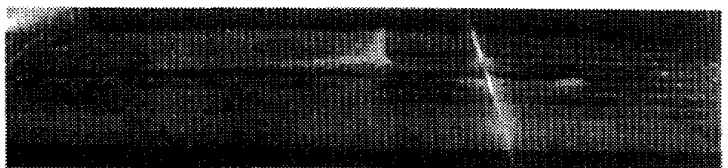

(b) $q_{w}=60 \mathrm{~W} / \mathrm{m}^{2}$

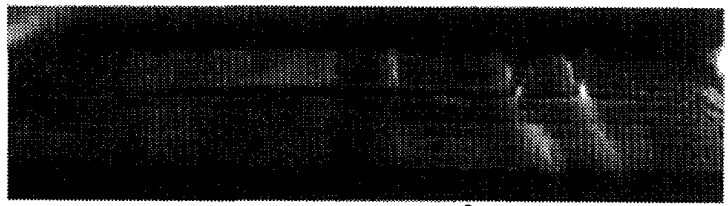

(c) $q_{w}=100 \mathrm{~W} / \mathrm{m}^{2}$

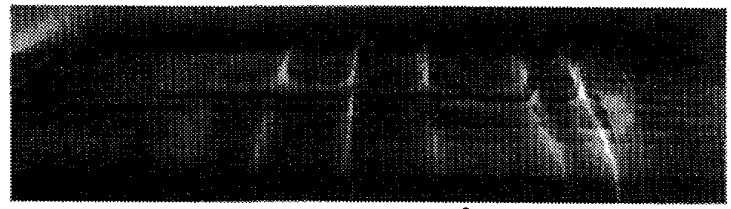

(d) $q_{w}=150 \mathrm{~W} / \mathrm{m}^{2}$

Fig. 4. Visualized flow field over plate (Air, $W=100 \mathrm{~mm}, u_{\infty}=0.12 \mathrm{~m} / \mathrm{s}$ )

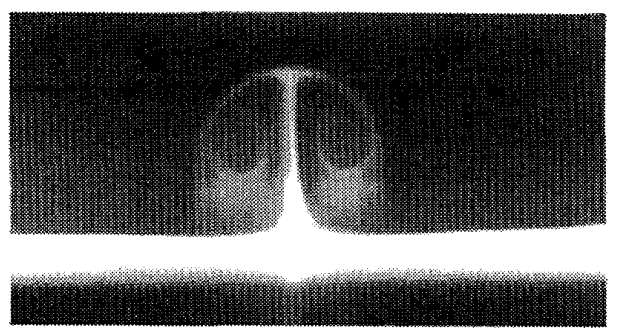

(a) Close-up of longitudinal vortex

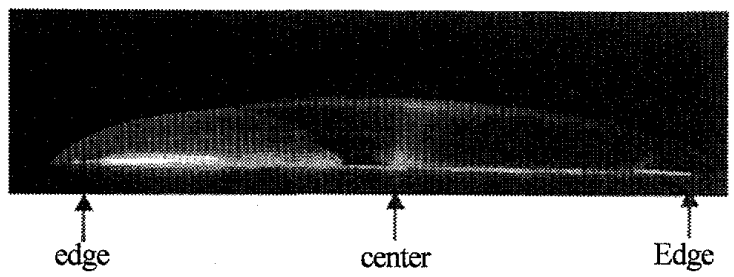

(b) Side view of longitudinal vortex

Fig.5 Visualization of longitudinal vortex

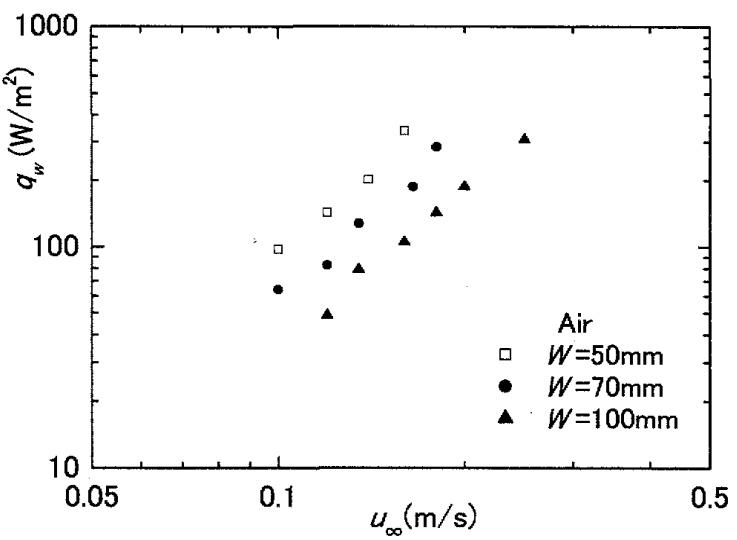

(b) Air

Fig.6 Conditions for the onset of longitudinal vortices 
は単純な層流よどみ点流れから変化していくことが分 かった.この縦渦がどのような条件で発生するかとい う問題は工学的に興味あるばかりでなく，前述した熱 CVD による均質薄膜形成の限界流速を明らかにする 上で重要と考えられる. そこで本研究では，これら流 れの可視化を，平板幅 $W$ ，主流速 $u_{\infty}$ およ熱流束 $q_{w}$ を系統的に変化させを場合について行い, 縦渦の発生 開始条件を調べてみた，その結果を水および空気につ いて，それぞれ図 6(a),(b) に示す．両図とも，横軸に 強制対流主流速度 $u_{\infty}$ をとり，縦軸にその流速条件下で， 平板上に縦渦が発生し始める熱流束 $q_{w}$ をプロットし たもので, 板幅 $W$ をパラメータにとっている.この両 図から，縦渦が発生し始める熱流束は，流速が低くな るに従って低くなること，また，板幅 $W$ が大きくなる ほど，より低い熱流束で縦渦が生じ始めることが分か る. とくに縱渦の発生が平板の大きさに依存する後者 の結果は，熱 CVD で基板上に均一な製膜を行なうに は，基板が大きくなるほど，より早い速度で原料ガス 老流す必要があることを示唆しており，重要な結果と 考えられる.

そこで本研究では，上の実験で得られた值を無次元 整理することにより，縱渦の発生を支配するパラメー タを探ってみた. 図7は，その結果を示したもので， 縦軸に板幅 $W$ を代表長さとする修正グラスホフ数 $G r_{W}{ }^{*}\left(=g \beta q_{w} W^{4} / \lambda v^{2}\right)$ をとり，横軸に同じくWを代 表長さとするレイノルズ数 $R_{W}\left(=u_{\infty} W / v\right)$ をとって 実験値を整理した結果を表している. 図 7(a) は水, 7(b) は空気の結果を示したものである.この両図から，水 および空気の実験值は，平板幅 $W$, 主流速度 $u_{\infty}$ おび 熱流束 $q_{w}$ の如何に依らず, 図中実線で示す直線のま わりにそれぞれまとまることが分かる.ここでこの 直線を式で表すと以下のようになった。

$$
\begin{aligned}
& G r_{W}{ }^{*} / R e_{W}{ }^{2.5}=4.0 \quad \text { (water) } \\
& G r_{W}{ }^{*} / R e_{W}{ }^{2.5}=1.77 \quad \text { (air) }
\end{aligned}
$$

これら図 7 中の実線よりも左上の領域では平板上に縌 渦が発生し，右下の領域では層流よどみ点流れが実現 される.また，上の結果は縦渦の発生が無次元パラメ 一タ $\left(\mathrm{Gr}_{W}{ }^{*} / \operatorname{Re}_{W}{ }^{25}\right)$ により支配されることを示してい る.

$3 \cdot 3$ 伝熱特性 前節の流れの可視化結果から， 浮力がある程度以上強くなると，水平上向き加熱平板 上に縦渦が発生することが明らかとなった，このよう な縦渦の発生は，平板まわりの伝熱特性に当然影響を 及ぼすであろう。そこで本研究では，つぎに平板の局 局所熱伝達率の測定を行い，平板上の流動之伝熱特性
との関連を調べることにした.

伝熱実験に先立ち，縦渦の発生が平板の伝熱特性に 及济寸影響を定性的に把握するため，感温液晶を平板 表面に貼り付け，温度分布の可視化を行なってみた. その代表的な結果を図 8 に示寸。この図 8 は，図 3,4 の流れの可視化と同様, 平板の横方向斜め上加写真 撮㔀したもので，原図はカラーである。モモクロの 本図では色の変化が不明であるが，図中の平板端部付 近の黒く見える部分が実際には茶褐色で温度が低い部 分を示している.また，図中白い矢印で記した個所に， 平板を横断する方向に筋が発生している様子が読み取 れるであろう。この箩の部分は害際には青色となって おり，温度が周辺に比べて高くなっている.

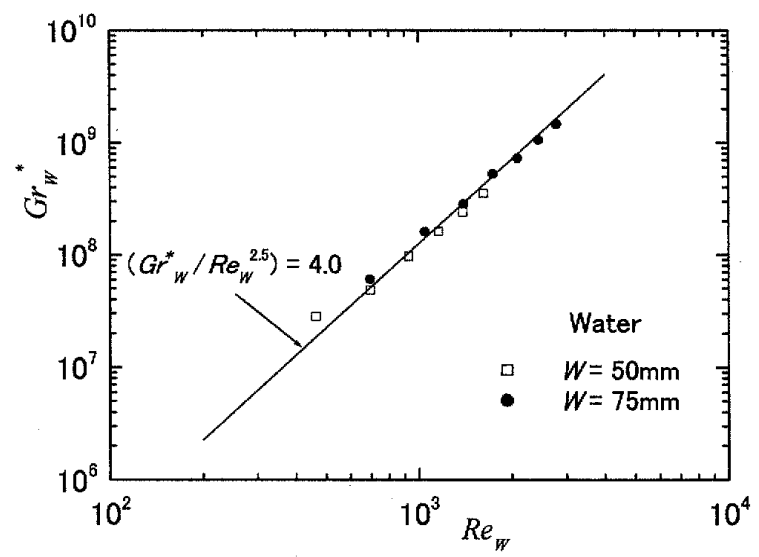

(a) Water

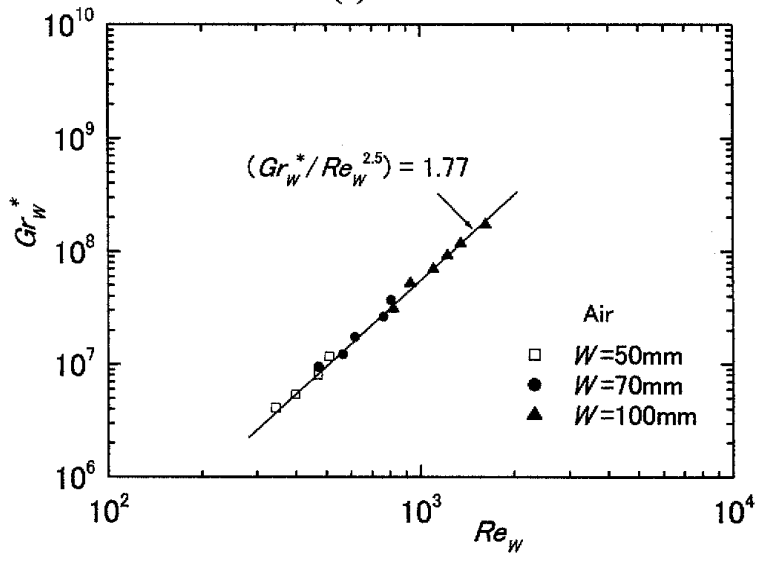

(b) Air

Fig.7 Non-dimensional condition for onset of longitudinal vortex

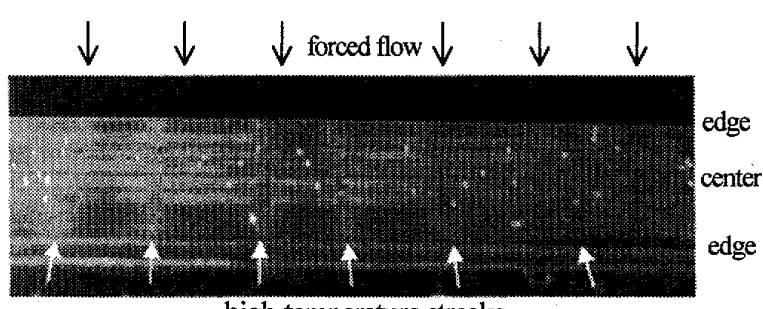

high-temperature streaks

Fig.8 Visualization of surface temperatures of test plate (Water, $W=75 \mathrm{~mm}, u_{\infty}=1.0 \mathrm{~cm} / \mathrm{s}, q_{w}=2000 \mathrm{~W} / \mathrm{m}^{2}$ ) 
この高温筋と図 3(d)に示した流れの可視化結果を対比 したところ，高温筋の部分は染料の筋が立ち上がる部 分に対応していることが分かった。 なお，この高温筋 も染料筋と同様，時間の経過に伴って平板のスパン方 向に移動していく.

以上の可視化結果を参考にして，つぎに熱電対を用 いて，平板の流れ方向の局所熱伝達率を定量的に測定 してみた。 そのうち, 主流流速が十分大きく, 平板上 に強制対流層流よどみ点流れが生じている場合の局所 熱伝達率を測定した例を図 9 に示す。この図 9 は, 空 気を試験流体とし, 幅 $50 \mathrm{~mm}$ の平板中心から流れ方向 距離 $x$ の地点における局所熱伝達率 $h_{x}$ をプロットした ものである. 流速を $u_{\infty}=0.20 \mathrm{~m} / \mathrm{s}$ 一定に保ち, 熱流束を 順次増加させている. なお，この流速条件下では，図 6(b)に示したように熱流束が最大となる $q_{w}=250 \mathrm{~W} / \mathrm{m}^{2}$ でも平板上に縦渦は発生しない，ところで, 本研究で 取り扱うよどみ点流れについては，くさび角 $\pi$ 層流 くさび流れとみなすことができる.この層流くさび流 れについては, 相似変数を用いた流動・伝熱解析が甲

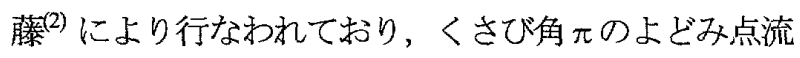
れに対しては，以下のような伝熱相関式が提案されて いる.

$$
N u_{f}=0.712 P^{0.4} \operatorname{Re}_{W}^{1 / 2}
$$

ここで, $N u_{f}$ およ゙ $\mathrm{Re}_{W}$ は板幅基隻の平均ヌッセルト 数 $\left(=h_{m f} \cdot W / \lambda\right)$ およびレイノルズ数 $\left(=u_{\infty} W / v\right)$ であり, 上 式の適用範囲は $P r=0.5 \sim 5$ である. 比較のため, この 相似解から算出した熱伝達率を図 9 中に実線で記した。

さて，本害験で得られた局所熱伝達率は，図中に記 した熱流束範囲内では熱流束に依存せず，ほぼ同一の 分布を示すこと，また，実験值は平板中心付近では解 析解に一致しているのに対して, 平板の端部にいくほ ど高い值を示すことが分かる. なお，水を試験流体と した場合にも，これと同様な結果が得られている。こ のように実験值と解析值が相違する原因であるが，解 析と実験との体系の違いが考えられる. 寸なわち，く さび流れの解析では長さ無限の平板が無限に広い一様 流中に設置された体系を想定しているのに対して，本 実験では平板の大きさは有限であり，一様流が実現さ れる領域も有限な大きさのダクト内に限られる.この ため, 平板による流れのブロッケージが生じ，平板表 面に沿ら境界層外縁速度が平板端部に行くほど加速さ れること，また，平板端部付近で流れの方向が急激に 変化することなどによって，熱伝達率が平板端部に向 かって高くなると考えられる．なお，本体系と若干体 系が異なるが, 有限な大きさの加熱角柱前面の熱伝達
率を測定した五十嵐(5)の実験でも，熱伝達率が角柱端 部に行くにつれて高くなる結果が報告されている.

さて，上述した局所熱伝達率が熱流束に依存しない 結果は強制対流の特徵と考えられる，そこで，本研究 ではこの強制対流の伝熱特性を平板の平均ヌッセルト 数を算出することにより調べてみた. 図 10 は, 強制対 流が支配的と考えられる条件下で，平板の平均ヌッセ ル下数 $N u_{f}\left(=h_{m f} \cdot W / \lambda\right)$ を求め, 横軸にレイノルズ数 $R e_{W}$ (= $\left.u_{\infty} W / v\right)$ をとって実験值を整理した結果を示したも のである.この図から，水および空気に対する本実験 結果はいずれもレイノルズ数の $1 / 2$ 乗に比例し，以下 のように表せることが分かる。

$$
\begin{array}{ll}
N u_{f}=1.62 R e_{W}{ }^{1 / 2} & \text { (for water) } \\
N u_{f}=0.72 R e_{W}{ }^{1 / 2} & \text { (for air) }
\end{array}
$$

なお，これら実験值は前述したように平板端部付近で 熱伝達率が層流くさび流れの值より高くなるため, 図 中点線で記した甲藤の伝熱相関式(6)から予測される 值に比べて, 空気の場合約 $20 \%$, 水の場合約 10\%程度 高い值を示している.

以上の強制刘流の実験結果を踏まえて，つぎに平板 上に縦渦が生じるような強い浮力作用下での伝熱特性

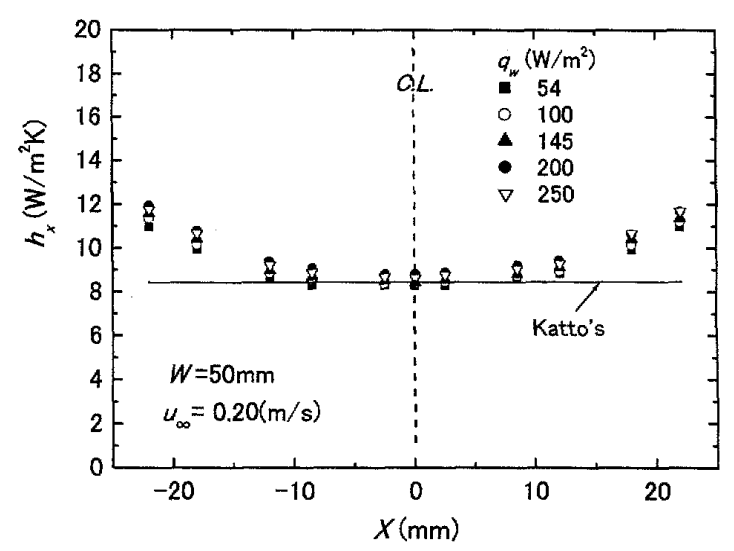

Fig.9 Local heat transfer coefficients for forced convection (Air, $W=50 \mathrm{~mm}, u_{\infty}=0.2 \mathrm{~m} / \mathrm{s}$ )

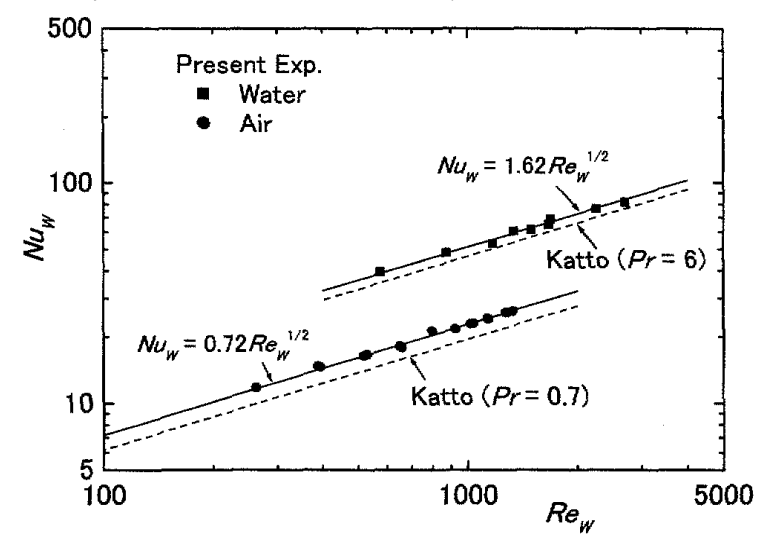

Fig.10 Average Nusselt numbers for forced convection 
を探ることにする. 図 11 は, 強制対流流速が比較的低 い条件下で, 平板の局所熱伝達率を測定した例を水 (図 11(a)）および空気 (図 11(b)) について示したもので ある. 両図とも図 10 と同様, 平板中心から距離 $x$ の地 点における熱伝達率をプロットし, 式(6)から計算した 強制対流くさび流れの解析值を実線で記した. まず, 図11(a)の水の結果であるが，熱流束が低い $q_{w}=1000$, $2000 \mathrm{~W} / \mathrm{m}^{2}$ の場合, 熱伝達率は熱流束によらずほぼ同 一の分布を示し，とくに平板中心付近ではくさび流れ の解析值に一致することが分かる。一方， $q_{w}$ が 5000 $\mathrm{W} / \mathrm{m}^{2}$ を越えた辺りから, 熱伝達率は熱流束に依存す るようになり， $q_{w}$ の増加と共に平板全面に亘って単調 に高くなっていく.これと同様な結果は, 図 11(b)の空 気の場合についてもいえる。すなわち，この場合熱流 束が $q_{w}=34 \mathrm{~W} / \mathrm{m}^{2}$ 以下で憢伝達率は一定な分布を示 すのに対して，69W/ $\mathrm{m}^{2}$ 以上になると，熱流束ととも に熱伝達率は単調に高くなっていく。これら平板の熱 伝達率が増加し始める条件と, 図6に記した縦渦の発 生開始条件を対比してみると，両者はほぼ一致してい ることが分かる，では，縦渦が発生するとなぜ熱伝達 率が高くなるかという問題であるが, これは図 12 に模 式的に示したように，平板上に縦珮が発生すると，縦 渦の立ち上がり部分(Stem) に向からスパン方向の流 れが生じ，この流れによって平板に沿う境界層厚さが 薄くなるためと考えられる. なお，この境界層の厚さ $\delta$ であるが，層流くさび流れの相似解析解(の基に計 算したところ, 本実験範囲内では $\delta=2 \sim 6 \mathrm{~mm}$ 程度の值 となった. これに対して, 縦渦のスケールは加熱条件 によって大きく異なるが，境界層厚さのおよそ数倍程 度のスケールを有している.

さて，本研究では上述した平板の局所熱伝達率の測 定を，平板幅 $W$ ，熱流束 $q_{w}$ およひ強制対流流速 $u_{\infty}$ を 系統的に変化させた場合について行なっている. そこ で，これらの測定により得られた局所熱伝達率から

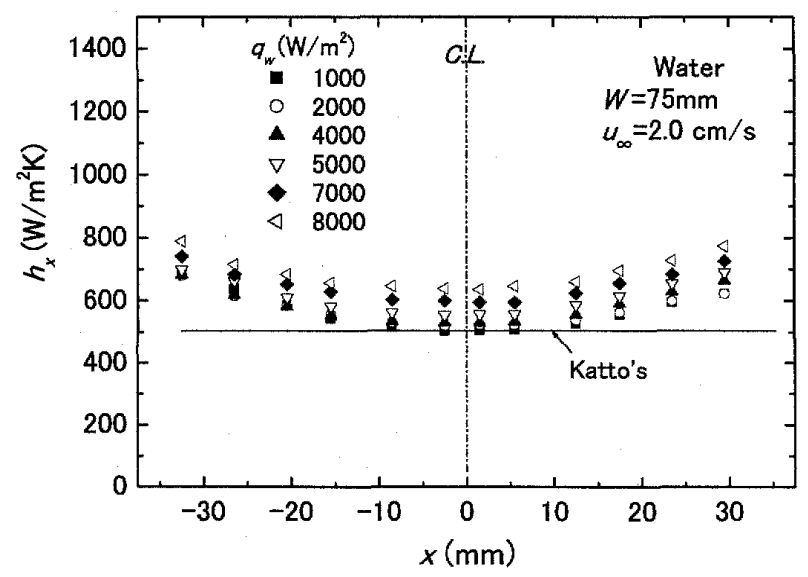

(a) Water

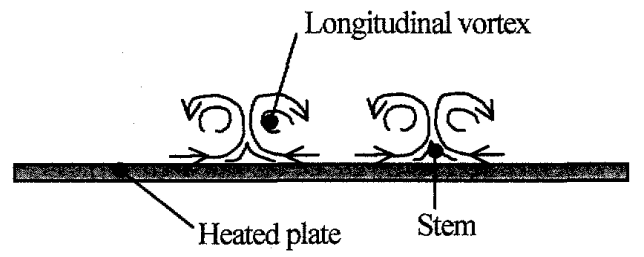

Fig. 12 Mechanisms of heat transfer enhancement by vortex

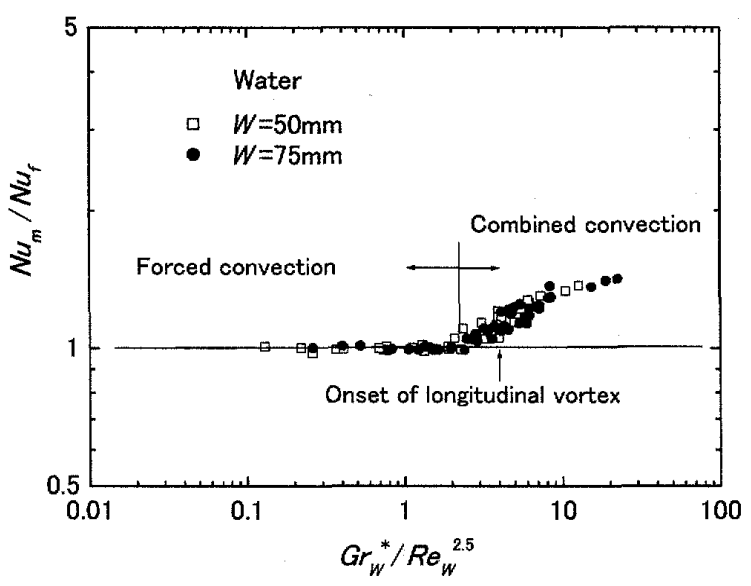

(a) Water

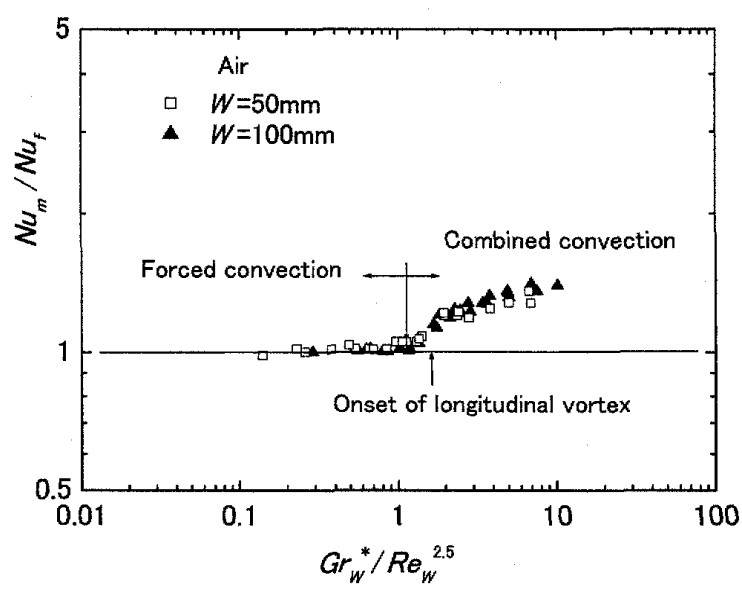

(b) Air

Fig.13 Non-dimensional conrelation for average Nusselt numbers

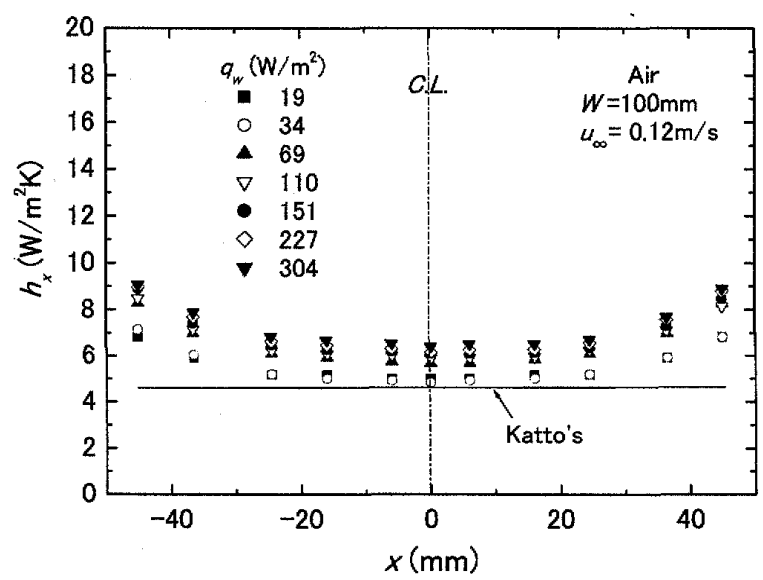

(b) Air

Fig. 11 Local heat transfer coefficients of combined convection 
平板の平均ヌッセルト数 $N u_{m}$ を求め，この平均ヌッセ ルト数について各種の無次元整理を試みることにより, 平板まわりの伝熱特性と流動との関連を探ることにし た. その結果，最もデータが良くまとまったのが，縦 軸に実験で得られた平板の平均ヌッセルト数 $N u_{m}$ をそ れと同じレイノルズ数 $R e_{W}$ におけるよどみ点流れの 平均ヌッセルト数 $N u_{f}$ で割った值 $\left(N u_{m} / N u_{f}\right)$ をとり, 横軸に浮力と慣性力の比を示す無次元パラメータ $\left(G r_{W}{ }^{*} / R e_{W}^{2.5}\right)$ をとって整理した場合であった.ここで， よどみ点流れの平均ヌッセルト数 $N u_{f}$ は，式(7)おうよ゙ 式(8)から求めた：このように整理すると，水および空 気に対する本実験值は，若干のばらつきが認められる ものの，平板幅 $W$ ，熱流束 $q_{w}$ ，主流流速 $u_{\infty}$ の如何に 依らず，それぞれ図 13(a)および図 13(b) に示すように まとまった．また，これら両図より，無次元パラメー 夕 $\left(G r_{W}{ }^{*} / R e_{W}{ }^{2.5}\right)$ の值が, 水の場合およそ 2.5 , 空気の場 合およそ 1.2 以下の領域では，平板の平均ヌッセル下 数 $N u_{m}$ が，よどみ点流れのヌッセルト数 $N u_{f}$ に一致す ることが分かる.このスッセルト数が一致する領域を， 本研究では強制対流域と定義すると, 強制対流域は水 および空気について，それぞれ $\left(G r_{W}{ }^{*} / R_{W}{ }^{2.5}\right)<1.2$, $\left(G r_{W}{ }^{*} / R e_{W}{ }^{2.5}\right)<2.5$ と表される. 一方, $\left(G r_{W}{ }^{*} / R e_{W}{ }^{25}\right)$ の 值がこれよりも大きくなると，平均ヌッセルト数は強 制対流値よりも高くなる. 従って，この領域は共存対 流域と見なせる.さらに，これら平均ヌッセルト数か ら求めた強制一共存対流のしきい值 $\left(G r_{W}{ }^{*} / R e_{W}{ }^{2.5}\right)$ と, 図 13 中に矢印で示した縦渦が生じ始める条件とを比 較してみると，前者の方が水および空気とも若干では あるが低く，平板上に縦渦が生じ始める以前に，熱伝 達率はよどみ点流れの值よりも高くなり始めているこ とが分かるる。

以上，本研究では系統的な流れの可視化および局所 熱伝達率の測定を通じて，水平上向き加熱平板まわり に生じる共存対流の流動と伝熱について検討を行なっ た，著者らの知る限り，このような実験を遂行した例 は他に無く，本研究で得られた一連の成果は，熱 CVD 法による薄膜形成問題，あるいは様々な発熱機器の熱 設計を行うための基礎資料として，また今後試みられ るであろう数值解析の検証用データベースとして活用 されるものと考えている.

\section{4. 結言}

本研究では，一様な流速で鈆直下方に流れる流体中 に，有限な大きさの加熱平板を流れに直交して，水平 上向きに設置した場合について，平板まわりに生じる 強制一自然共存対流の流動と伝熱を，可視化およひ伝
熱実験により探った．試験流体にはプラントル数の異 なる水および空気を用い，試験平板には等熱流束条件 で加熱した 2 次元平板を用いた. 実験は平板幅 $W$ 基準 のレイノルズ数 $R e_{W}$ および修正レイリ一数 $R a_{W}{ }^{*}$ が, 水については, $300<R e_{W}<5000,10^{7}<R a_{W}{ }^{*}<10^{10}$, 空 気については, $200<R e_{W}<2000,10^{6}<R a_{W}{ }^{*}<10^{9}$ の範 囲で行った

まず上向き加熱平板上の流れを，染料および煙によ り可視化してみた，その結果，以下の知茪が得られた。

(1) 浮力が小さな場合，平板上には平板中心を岐点 とする層流よどみ点が生じる，一方，浮力がある值よ りも大きくなると，平板上には流れ方向に軸をもつ縦 渦が生じ始め，さらに浮力を増加させていくと，この 縦渦の数が増えると共に，スケールも大きくなる.

(2)この縱渦が平板上に発生し始める条件は，浮力 と慣性力の比を表す無次元パラメータ $\left(G r_{W}{ }^{*} / \operatorname{Re}_{W}{ }^{2.5}\right)$ に よって予測でき，水の場合 $\left(G r_{W W}{ }^{*} / R e_{W}{ }^{2.5}\right)=4.0$, 空気の

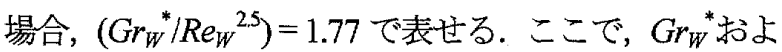
び $R e_{W}$ は，平板幅 $W$, 強制対流主流流速 $u_{\infty}$ ，熱流束 qwをそれぞれ代表長さ，速度およひ熱流束とする修正

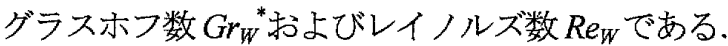

つぎに平板の局所および平均熱伝達率を測定した。 その結果，以下の知見が得られた。

(3) 平板の局所熱伝達率は，上述した縦渦の発生に 伴って，層流よどみ点流れのそれよりも高くなる。

(4) 平板の平均ヌッセルト数は, 無次元パラメータ $\left(G r_{W}{ }^{*} / R e_{W}{ }^{2.5}\right)$ により整理でき, このパラメータの值が, 水の場合 $\left(G r_{W}{ }^{*} / R e_{W}{ }^{2.5}\right)<2.5$, 空気 $\sigma$ 場合 $\left(G r_{W}{ }^{*} / R e_{W}{ }^{2.5}\right)<$ 1.2 では，よどみ点流れのヌッセルト数に一致する。一 万， $\left(G r_{W}{ }^{*} / R e_{W}{ }^{2.5}\right)$ の值吕上の值よりも大きければ，よど み点流れの平均ヌッセルト数よりも高くなる.

\section{文献}

(1) Hiemenz, K., Die Grenzschlicht an einem in den gleighförmigen Flüssigkeitsstrom eingetauchten geraden Kreiszylinder, Göttingen Dingl. Polytech. $J$. 326(1911) pp.321.

(2) Katto, Y., Outline of Heat Transfer (in Japanese), (1977), p.71, Yokendo Ltd.

(3) Chen, K., Chen, M.M. and Sohn, C.W., Thermal Instability of Two-Dimensional Stagnation Point Boundary Layers", J. Fluid Mechanics, Vol.132 (1983), pp.49-63.

(4) Amaouche, M. and Boukari, D., "Influence of Thermal Convection on Non-orthogonal Stagnation Point Flow", International Journal of Thermal Sciences, Vol.42 (2003), pp.303-310.

(5) Igarashi, T., Fluid Flow and Heat Transfer around a Square Prism, Transactions of the Japan Society of Mechancal Engineers, Series B, 50-452 (1984), pp.1173-1181.

(6) Schlichting, H., "Boundary-Layer Theory(7th.ed.)", p.817 (1979), McGraw-Hill. 